\title{
Health risk assessment of arsenic dispersion from mining in Mount Isa
}

\author{
J. Zheng ${ }^{1}$, B.N. Noller ${ }^{1}$, T. Huynh ${ }^{1}$, R. Taga ${ }^{1,2}$, J.C. $\mathrm{Ng}^{2,3}$, V. Diacomanolis ${ }^{2}$ \& H.H. Harris ${ }^{3}$ \\ ${ }^{1}$ Centre for Mined Land Rehabilitation, Sustainable Minerals Institute, \\ The University of Queensland, Brisbane, QLD, Australia \\ ${ }^{2}$ Queensland Alliance for Environmental Health Sciences (QAEHS), \\ The University of Queensland, Brisbane, QLD, Australia \\ ${ }^{3}$ Cooperative Research Centre for Contamination Assessment and Remediation of the Environment (CRC CARE), \\ Newcastle, NSW, Australia \\ ${ }^{4}$ Department of Chemistry, Adelaide University, Adelaide, SA, Australia
}

\begin{abstract}
The study identified that arsenic (As) exposure to the population of Mount Isa is of limited significance but surface tailings and fall out (city) may be higher risk because their \% bioaccessibilities are higher than those of other sources. Total As concentrations $\left(\mu \mathrm{g} \mathrm{m}^{-2}\right)$ in surface wipes indicate a need to clean surfaces where children regularly contact. Airborne particulate concentrations were not significant for the sampling period.
\end{abstract}

\section{INTRODUCTION}

The Lead Pathway Air Study (2007-2012) has also examined sources of arsenic (As) and provided an understanding of human exposure at Mount Isa from mining and processing activities (Noller et al., 2017). If not properly managed, dispersion of metals and metalloids from mine activities may cause adverse effects on the environment and human health. The National Environment Protection Measures (NEPMs) guidelines for soil contamination in Australia (NEPC, 2013) identify a need to undertake further Tier II risk assessment of the site if the Health Investigation Levels (HIL) are exceeded. In the absence of site specific data, the NEPMs may not provide accurate close out criteria for mined land. The aim of this study is to use a risk assessment process to assess any potential health effects from As sources in Mount Isa city including from mining and mineral processing, natural and other sources of exposure to the local population.

\section{METHODS/EXPERIMENTAL}

Samples of ores and processed materials were collected from Mount Isa Mines, and soil and dust from the nearby city (Noller et al., 2017). Samples initially sieved to $<2 \mathrm{~mm}$ for measurement of total concentrations (aqua regia digest) were also sieved to $<250 \mu \mathrm{m}$ for bioaccessibility (gastro-intestinal tract simulation) measurement using the physiologically-based extraction test ( $\mathrm{Ng}$ et al., 2015; Ruby et al., 1996). Air particulates and surface wipes were also collected (Noller et al., 2017). Arsenic concentrations were determined in digest solutions by ICP-MS. Particle size analysis was undertaken by Malvern Mastersizer (2000). Hazard assessment, exposure assessment and risk characterization of arsenic followed the Australian enHealth (2012) health risk assessment framework.

\section{RESULTS AND DISCUSSION}

Table 1 gives results for total As and bioaccessibleadjusted concentrations $\left(\mathrm{mg} \mathrm{kg}^{-1}\right)$ in soil, minerals and dusts from Mount Isa and environs. Whilst some total As concentrations exceed NEPM HILs, only surface tailings and fall out (city) exceed HIL A for bioaccessibility adjusted As concentration (Table 1). Total As concentrations $\left(\mu \mathrm{g} \mathrm{m}^{-2}\right)$ in surface wipes at Mount Isa city (Table 2) show that floor and carpet surfaces, based on an indicative guideline, have much lower concentrations than window sill and trough and external surfaces which are not cleaned in houses and regularly as floors and carpets. These data indicate a need to clean surfaces that children regularly contact. Table 3 gives airborne concentrations of As $\left(\mu \mathrm{g} \mathrm{m}^{-3}\right)$ in outdoor and indoor air at the Mount Isa residential area and show that the As guideline for total suspended particulates was not exceeded for the period of sample collections. Bioaccessibility (\% BAc, in-vitro) is generally a more conservative approach to estimate bioavailability of contaminated wastes such as from mining. Figure 1 shows the particle size distribution of samples from the mine site and residential area as cumulative (\%). All samples have $50 \%$ of volume in the range $10-110 \mu \mathrm{m}$ except for surface tailings with $50 \%$ of volume being $1 \mu \mathrm{m}$ but bimodal. This data 
Table 1. Total As concentrations and bioaccessible As in soil and dust samples from Mount Isa.

\begin{tabular}{|c|c|c|c|}
\hline \multirow[b]{2}{*}{ Sample } & \multirow{2}{*}{$\begin{array}{l}\text { Total As } \\
\left(\mathrm{mg} \mathrm{kg}^{-1}\right) \\
\text { Mean } \pm \operatorname{sd}\left(\mathrm{n}^{*}\right)\end{array}$} & \multicolumn{2}{|c|}{$\begin{array}{l}\text { Bioaccessibility (BAc) } \\
\text { Mean } \pm s d\left(n^{*}\right)\end{array}$} \\
\hline & & $\begin{array}{l}\text { Adjusted } \\
\left(\mathrm{mg} \mathrm{kg}^{-1}\right)\end{array}$ & $\mathrm{BAc} \%$ \\
\hline \multicolumn{4}{|c|}{ Background geology } \\
\hline Outcrops & $31 \pm 27(13)$ & $3 \pm 2.1(5)$ & $9 \pm 6(5)$ \\
\hline Mineralization & $497 \pm 197(4)$ & $7(1)$ & $1(1)$ \\
\hline \multicolumn{4}{|c|}{ Mining and mineral processing } \\
\hline Mine site dust & $1320 \pm 4040(72)$ & $25 \pm 23(16)$ & $8 \pm 6(16)$ \\
\hline Haul road dust & $291 \pm 3(9)$ & $32 \pm 27(9)$ & $11 \pm 4(9)$ \\
\hline Tailings surface & $361 \pm 31(7)$ & $112 \pm 96(7)$ & $31 \pm 28(7)$ \\
\hline Smelter dust & $375 \pm 525(16)$ & $30 \pm 42(22)$ & $8 \pm 5(22)$ \\
\hline \multicolumn{4}{|c|}{ City residential area } \\
\hline $\begin{array}{l}\text { Garden soil } \\
(<250 \mu \mathrm{m})\end{array}$ & $12 \pm 9(76)$ & $2 \pm 2(76)$ & $15 \pm 8(76)$ \\
\hline $\begin{array}{l}\text { Garden soil } \\
(<10 \mu \mathrm{m})\end{array}$ & $39 \pm 28(74)$ & $11 \pm 11(74)$ & $28 \pm 15(74)$ \\
\hline Footpath & $9 \pm 6(14)$ & $1.9 \pm 0.9(14)$ & $27 \pm 14(14$ \\
\hline Fallout dust & $291 \pm 248(15)$ & $130 \pm 90(15)$ & $47 \pm 23$ \\
\hline $\begin{array}{l}\text { Roof gutter } \\
\text { dust }\end{array}$ & $\begin{array}{l}1139 \pm 1511 \\
(18)\end{array}$ & $52 \pm 54(18)$ & $11 \pm 10$ \\
\hline Carpet dust & $46 \pm 26(6)$ & $9 \pm 7(6)$ & $22 \pm 10(6)$ \\
\hline
\end{tabular}

Australian soil contamination guidelines (NEPC 2013)

HIL A 100

(residential/

garden)

HIL C (public 300

open space)

$* \mathrm{n}=$ number of samples.

Table 2. Total As concentrations $\left(\mu \mathrm{g} \mathrm{m}^{-2}\right)$ in surface wipes.

\begin{tabular}{|c|c|}
\hline Sample & Total As $\left(\mu \mathrm{g} \mathrm{m}^{-2}\right)$ mean $\pm \mathrm{sd}\left(\mathrm{n}^{*}\right)$ \\
\hline Floor wipe & $17 \pm 48(176)$ \\
\hline Carpet wipe & $13 \pm 4(68)$ \\
\hline Window sill & $102 \pm 235(130)$ \\
\hline Window trough & $2163 \pm 5140(47)$ \\
\hline Roof wipe & $1247 \pm 2834(134)$ \\
\hline Veranda wipe & $146 \pm 248(84)$ \\
\hline \multicolumn{2}{|c|}{ Guideline (Brookhaven National Laboratory 2014) } \\
\hline Surface wipe for As & $1500 \mu \mathrm{g} \mathrm{m}^{-2 *}$ \\
\hline
\end{tabular}

${ }^{*} \mathrm{n}=$ number of samples; Criteria type - Housekeeping - all.

supports that tailings surface material and city fall out may be higher risk because their \% BAc's (Table 1) are 31 and 47 , respectively.

\section{CONCLUSIONS}

The study identified that As exposure to the population of Mount Isa is low but surface tailings and fall out (city) may be higher risk because their \% BAc's are higher than those of other sources. Total As concentrations $\left(\mu \mathrm{g} \mathrm{m}^{-2}\right)$ in surface wipes indicate a need to clean surfaces where children regularly contact.
Table 3. Airborne As concentrations $\left(\mu \mathrm{g} \mathrm{m}^{-3}\right)$ in Mount Isa.

Sample $\quad$ Total As $\left(\mu \mathrm{g} \mathrm{m}^{-3}\right)$ Mean $\pm \mathrm{sd}\left(\mathrm{n}^{*}\right)$

City outdoor

$\begin{array}{ll}(2009) & 0.005 \pm 0.008(12) \\ (2010) & 0.005 \pm 0.008(12) \\ (2011) & 0.005 \pm 0.008(12)\end{array}$

(2011)

City Indoor

(2010)

$0.004 \pm 0.004(12)$

Guideline (NEPC 2002)

As in total suspended $\quad 0.006 \mu \mathrm{g} \mathrm{m}^{-3}$ particles ('TSP')* (1 year averaging period)

$* \mathrm{n}=$ number of samples.

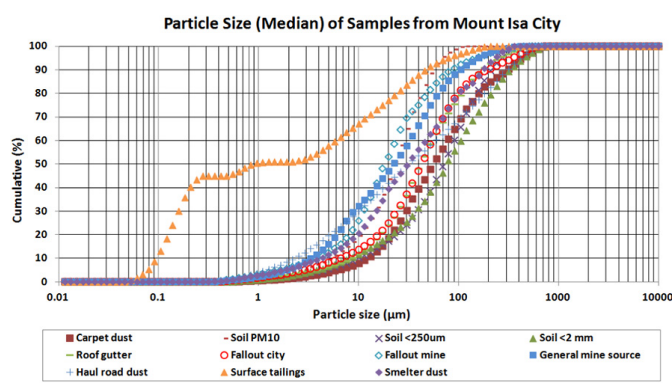

Figure 1. Particle size distribution of samples from the mine site and residential area as cumulative (\%).

Airborne particulate concentrations were not significant for the sampling period.

\section{ACKNOWLEDGEMENTS}

Glencore- Mount Isa Mines funded the study.

\section{REFERENCES}

enHealth 2012. Environmental health risk assessment. Guidelines for assessing human health risks from environmental hazards. The Environmental Health Committee.

NEPC 2002. Ambient air quality standards. National Environment Protection Council. Canberra.

NEPC 2013. National Environmental Protection (Assessment of Site Contamination) Measures, National Environment Protection Council, Adelaide.

Ng, J.C., Juhasz, A., Smith, E. \& Naidu, R. 2015. Assessing bioavailability and bioaccessibility of metals and metalloids. Environ. Sci. Pollut. R. 22(12): 8802-8825.

Noller, B., Zheng, J., Huynh, T., Ng, J., Diacomanolis, V., Taga, R. \& Harris, H. 2017. Lead Pathways Study - Air. Health Risk Assessment of Contaminants to Mount Isa City. 7 February 2017 Mount Isa Mines Limited, Mount Isa. pp 1-414 plus appendices. http://www.mountisamines .com.au/EN/sustainability/Pages/LEADPATHWAYS STUDYPORTAL.aspx.

Ruby, M.V., Davis, A., Schoof, R., Eberle, S. \& Sellstone, C.M. 1996. Estimation of lead and arsenic bioavailability using a physiologically based extraction test. Environ. Sci. Technol. 30(2): 422-430. 